\title{
Bacterial diversity of river Kshipra with relation to human health
}

\author{
Bhasin Shivi, Shukla Arvind N. and Shrivastava Sharad $凶$
}

Received: 08.02.2020

Revised: 14.04.2020

Accepted: 23.04.2020

\begin{abstract}
Bacterial community has always been an essential component of aquatic ecosystem because of the important role played by it in maintaining continuity of ecosystem. Aquatic bacterial diversity has been an interesting, popular and wide area of research as it is well correlated with the level of pollution in the ecosystem. Addition of pollutants is one of the major factor which disturbs bacterial diversity and density in river. The aim of the present work is to investigate the presence of bacteria and analyze its correlation with pollution status in river Kshipra which is considered to be a holy river of central India. The study also records the occurrence of different bacterial species including fecal coliform, total coliforms and many other pathogenic bacteria. Presence of pathogenic bacteria like Salmonella sps., Pseudomonas sps. ,Shigella sps., Vibrio sps. and FC/FS ratio between 1.1-1.5 indicates that the river is contaminated by domestic and city sewage as well as by both animal and human excreta. The current investigation reports the occurrence of different water borne diseases like typhoid, cholera, gastrointestinal diseases and skin infections etc in people residing nearby river who consume river water for fulfilling their daily need. A strong correlation has been established between bacterial density and physicochemical parameters like temperature, Dissolved Oxygen, Biological Oxygen Demand and Chemical Oxygen Demand. Urgent measures should be taken by eminent authorities to minimize the anthropogenic activities like dumping of flower, oil, body ashes, coconut shell in order to restore this sacred river.
\end{abstract}

Keywords: Bacteria, Physicochemical parameter, River, Water Borne Diseases, Water Pollution.

\section{Introduction}

One of the major source of pollution in any river ecosystem is organic pollution as this type of pollution originates from domestic sewage (raw or treated),urban or industrial effluents and anthropogenic activities. It occurs mainly when large quantities of organic compounds are released into water courses and these compounds start acting as substrates for microorganisms.Decreased availability of oxygen in water, reduced fitness of organisms and severe asphyxiation are all consequences of increased organic pollution load in the water body (Bhasin,2016; Bhutiani and Khanna, 2002). Microorganisms are a diverse group of organism found in large quantities and are correlated with particular type of pollution present in the environment. Environment pollution affects the biological diversity of microbial community in a tropical fresh water system (Kochling et al. 2017). The organic pollution load in a water body can most commonly be detected by the presence of specific microorganisms in that particular water body. Author's Address

Limnology and Environmental Biotechnology Laboratory S.S. in Zoology and Biotechnology, Vikram University Ujjain (MP) E-mail.: shivib9@gmail.com
The organisms or chemical markers which can detect a change in the environment by their presence or absence and can denote the qualitative status of a water body are known as bio-indicators. Several Limnologists have discussed the importance of different microbes as indicator of freshwater pollution (such as Algae, Fungi, Bacteria and Protozoa etc.)(Khanna et al., 2006; Khanna et al. , 2008). The main cause of organic burden of sewage is human body waste and the microorganisms which are commonly associated with pollution are considered to be indicators of organic pollution. One such important bio indicator of organic pollution are bacteria. Khanna et al. (2011) Studied on pollution status and its impact on water quality of River Ganga at Haridwar. They are common single-celled organisms and are natural component of lakes, rivers and streams. Most bacteria are harmless to humans whereas some infect the interstitial track of humans. High bacteria (i.e. high FC and high TC) count in any water body indicates high organic pollution load whereas the presence of some specific genera of bacteria (like E.coli) indicates the presence of pathogenic bacteria. Bacteria are responsible for causing many 
water borne infections especially to people who rely on river water for their daily need. The current investigation deals with studying the occurrence of bacterial diversity in river Kshipra, viewing the effect of seasonal variation on the occurrence of bacteria, studying the correlation of bacterial diversity with physicochemical parameters and analyzing the effect of pathogenic bacteria on human health.

\section{Material and Methods}

Study Sites: The origin point of River Kshipra is Kakari Bardi a hill of Vindhya range, which is 12 $\mathrm{km}$ south-east of Indore city. According to environmental conditions and high anthropogenic activities 5 study sites have been selected on the banks of Kshipra river viz. Kshipra Village, Triveni, Ramghat Mangalnath and Mahidpur.

\section{Sampling Procedure}

Sampling was carried out monthly from November 2013 to October 2014. The bacterial samples were first isolated then collected and stored using 500 $\mathrm{ml}$. sterilized bottles. They were then kept in ice bucket and were transported to the base laboratory within a period of 24 hours. Qualitative and quantitative analysis of bacteria was performed at the base laboratory on monthly basis.

\section{Isolation and Identification of various Bacterial species}

Samples were diluted three times after which bacteria were isolated by using membrane filtration technique (APHA, 2005), then the membrane was dried and cultured on media (Maconkey agar, Nutrient agar, Di-chloro acetate agar, Brilliant Green, Blood agar Capzek agar TCBS) at $30-37^{\circ} \mathrm{C}$ for $24 \mathrm{hrs}$ (Plate 1). Sub culture of obtained colonies was done on different media after which species confirmation was done by applying different biochemical tests like colony characters, pigment production, gram staining, cytochrome, oxidase, catalase production, MR-VP, indole, oxidase, urease and $\mathrm{H}_{2} \mathrm{~S}$ etc. Categorization of all the strains was done according to Bergy's Manual of Systemic Bacteriology (Bergey 1985) and other bacteriological literature (Whiteman et al. 2012). Colonies were counted by using standard plate count (Plate 2).

\section{Assessment of physicochemical parameters}

Standard methods given in APHA (2005) were used to analyze different physicochemical parameters.

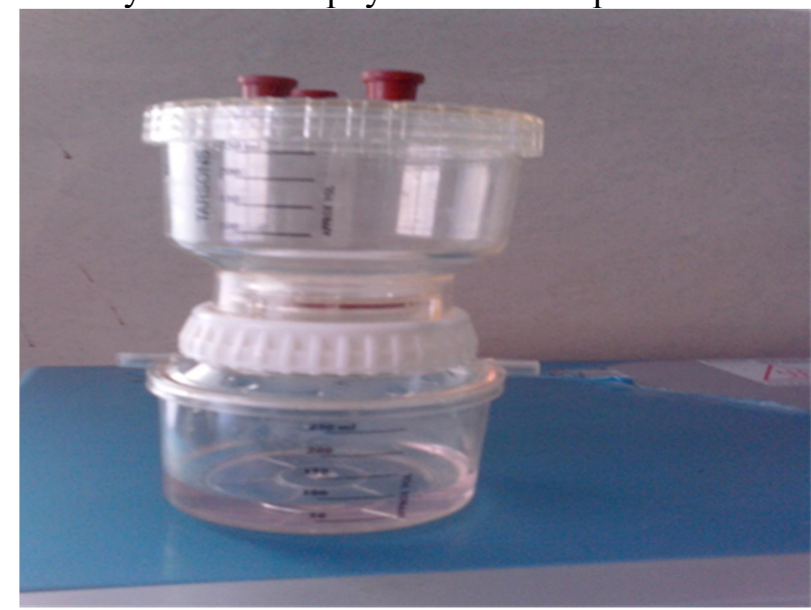

Plate 1.Membrane filtration apparatus

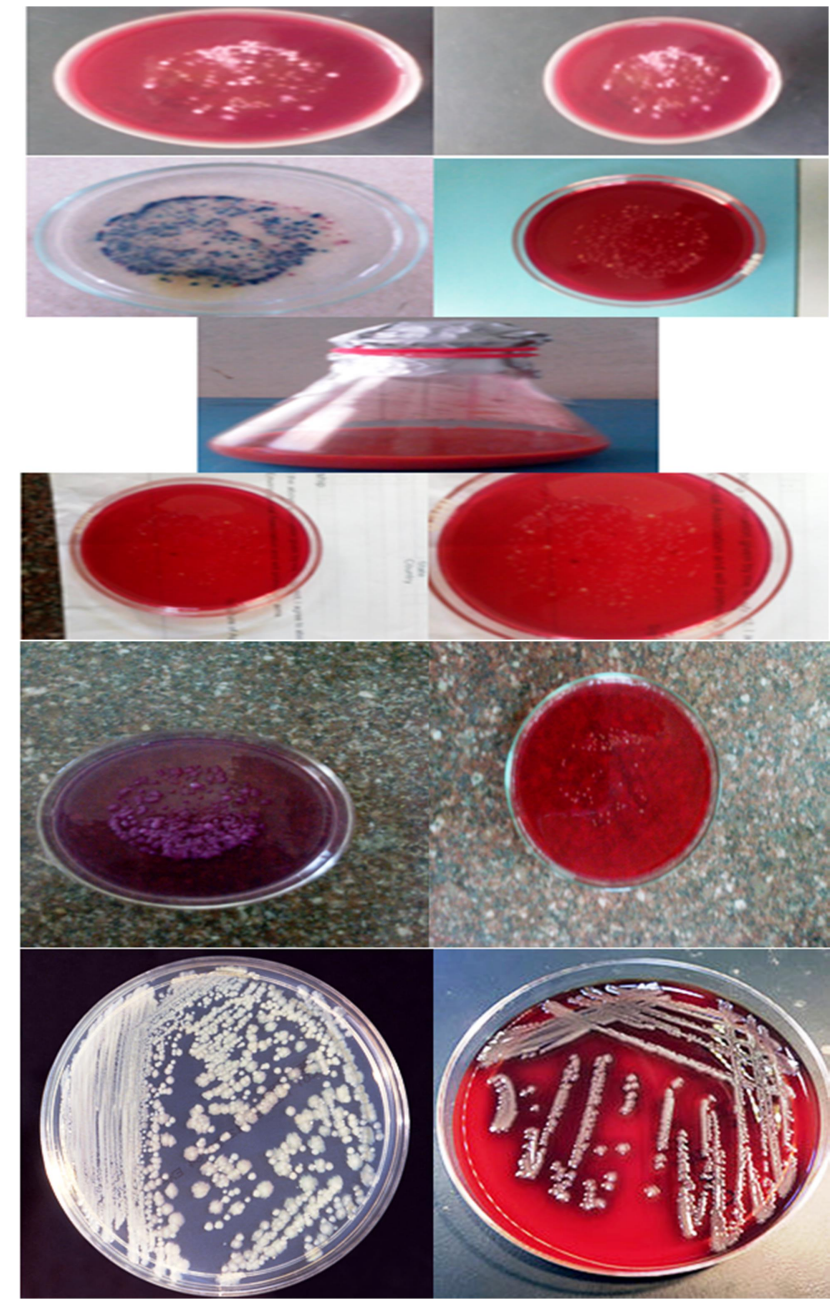

Plate 2. Some Bacterial Colonies 
Collection of data regarding water born diseases The count of people who suffered from water borne diseases has been collected by survey from major hospitals of Ujjain and Dewas city. Structural interview involving 500 households randomly selected from all the four quarters in the cities of Ujjain and Dewas were successfully taken. Respondents were required to furnish information on their sources of water for domestic use and the occurrence of water borne diseases in their respective families.

\section{Results and Discussion}

Spatial and temporal distribution of bacteria in river From qualitative point of view, studies on bacteria from all the five sites revealed a record of 35 species belonging to 11 genera during the study period. The recorded bacterial diversity reported, 2 species belonging to genera Escherichia, 5 to Streptococcus, 5 to Kiebsiella 2 to Enterobacter, 3 to Vibrio, 1 to Aeromonas, 4 to Shigella, 2 to Flavobacterium, 2 to Citrobacter, 4 to Pseudomonas and 5 to Salmonella. Bacterial diversity ranged between 13-26 sps. at Kshipra Village, 19-32 sps. at Triveni, 23-35 sps. at Ramghat, 22-34 sps. at Mangalnath and 16-29 sps. at Mahidpur. The minimum bacterial diversity (13 species) has been reported from Kshipra Village during the month of November and December whereas, maximum bacterial diversity (35 species) has been recorded from Ramghat study sites from March to June (Table 1. and Fig 1.).

Density of total bacterial count ranged between $126-390 \times 10^{3} \mathrm{CFU} / 100 \mathrm{ml}$. at Kshipra Village, 289$764 \times 10^{3} \mathrm{CFU} / 100 \mathrm{ml}$. at Triveni, 506$1190 \times 10^{3} \mathrm{CFU} / 100 \mathrm{ml}$. at Ramghat, 411$1026 \times 10^{3} \mathrm{CFU} / 100 \mathrm{ml}$. at Mangalnath and 194$427 \times 10^{3} \mathrm{CFU} / 100 \mathrm{ml}$. at Mahidpur . Quantitative analysis of bacterial population shows minimum density $158 \times 10^{3} \mathrm{CFU} / 100 \mathrm{ml}$ at Kshipra Village in the month of June, whereas maximum bacteria density $1190 \times 10^{3} \mathrm{CFU} / 100 \mathrm{ml}$ has been recorded in the month of June from Ramghat study site (Fig. 2). Both the qualitative and quantitative studies on bacterial population reveal that maximum diversity and density of bacteria have been reported in the month of June i.e. during summer season. The observation is attributed to the fact that during summer season water level is reduced due to which bacteria accumulate and settle as a result of greater contact between water and sediment which enables significant sediment water exchange (Mitsch and Grosslink 2000). Due to lack of rainfall a lot of fecal matter and associated waste accumulates on land which is washed into surface water and an upsurge in bacterial count during summer and early rainy season is recorded This increased count is a combination of contributions from such land stores and sediment re-suspention. In the mean time, due to regular rainfall fecal matter flushes from land and is deposited with the increased volume of water in river channels, which leads to maximum dilution resulting in lower counts. During winters, a reduced input from land stores through run-off with decreasing flow, settling out of sediment particles with associated bacteria is enhanced. The sediments thus start serving as as sinks of fecal bacteria. As a result of which, the bacteria counts remains low during this phase of hydrograph. The physiological and bacteriological characteristic of Noyal river has been reported by Vsharani et al. (2010).

As, far as the spatial distribution of bacteria is concerned, comparatively higher count of bacteria have been reported at Triveni, Ramghat and Mangalnath study sites which are attributed to high anthropogenic activities, worship rituals, dumping of flowers, coconut shells and body ashes at these sites. Moreover, presence of a crimnitorium and Shani temple at Triveni study site are responsible for excess pollution on the river at that particular site. Addition of oil on statue of lord Shani at the Shani temple is regularly seen which is then dumped into the river. At the same time, brick kling making activity are observed between Triveni and Ramghat study sites, this is accompanied by ingression of water into encroaching garbage. The waste dumps as well as overflow of poorly maintained septic tanks at Ramghat study site are another reason for adding to the pollution load at these particular sites. An increased and continuous re-suspension from streambed and allocthonous inputs from runoff, anthropogenic activities and dissolution of actively decomposing waste matter from Triveni to Mangalnath study sites are respectively observed leading to an increase in bacterial counts at these sites. The bacterial community is known to respond to changes in nutrients and pollutants in river water (Zhan et al. 2020). Low bacterial density has been witnessed from Kshipra Village and Mahidpur study sites as 


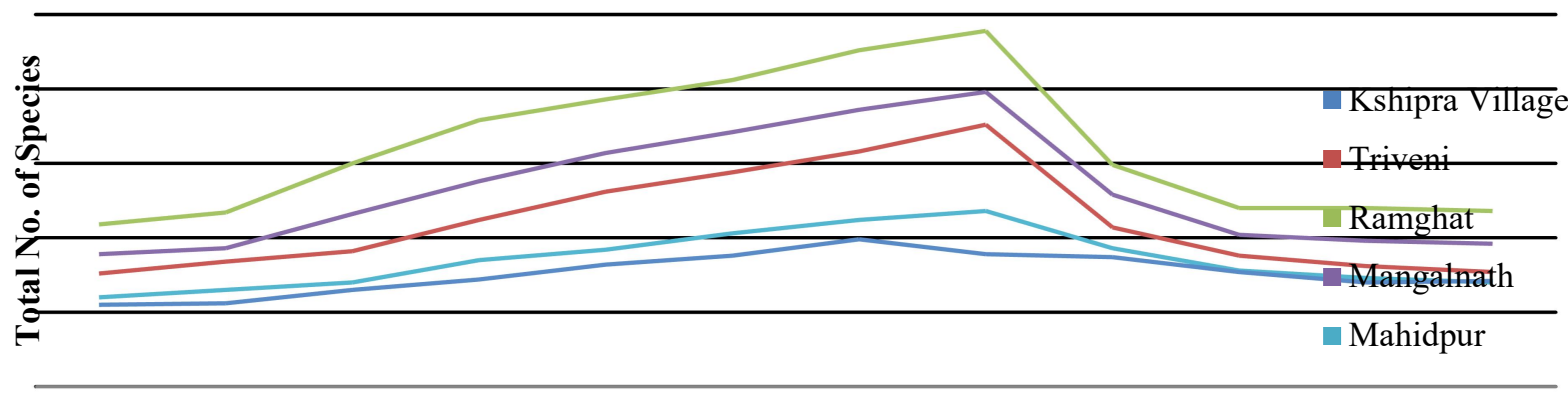

Fig 1. - Seasonal variations in bacterial diversity at different sites of Kshipra river.

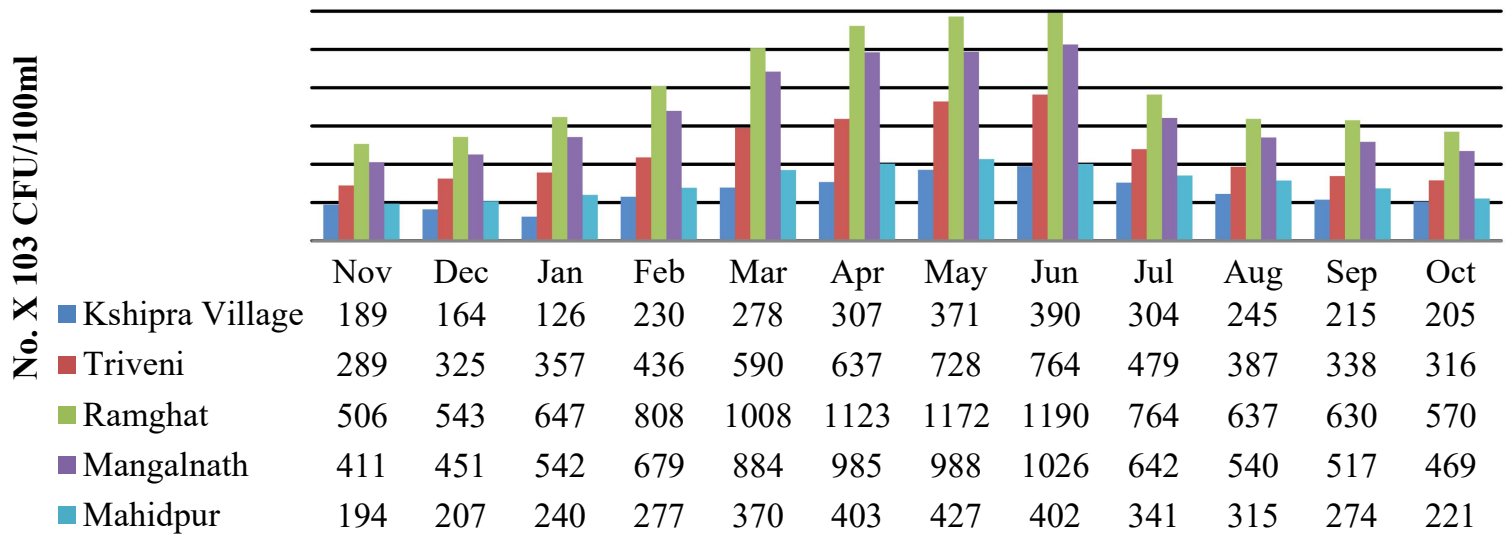

Fig 2. Seasonal variations in bacterial density at different sites of Kshipra river.

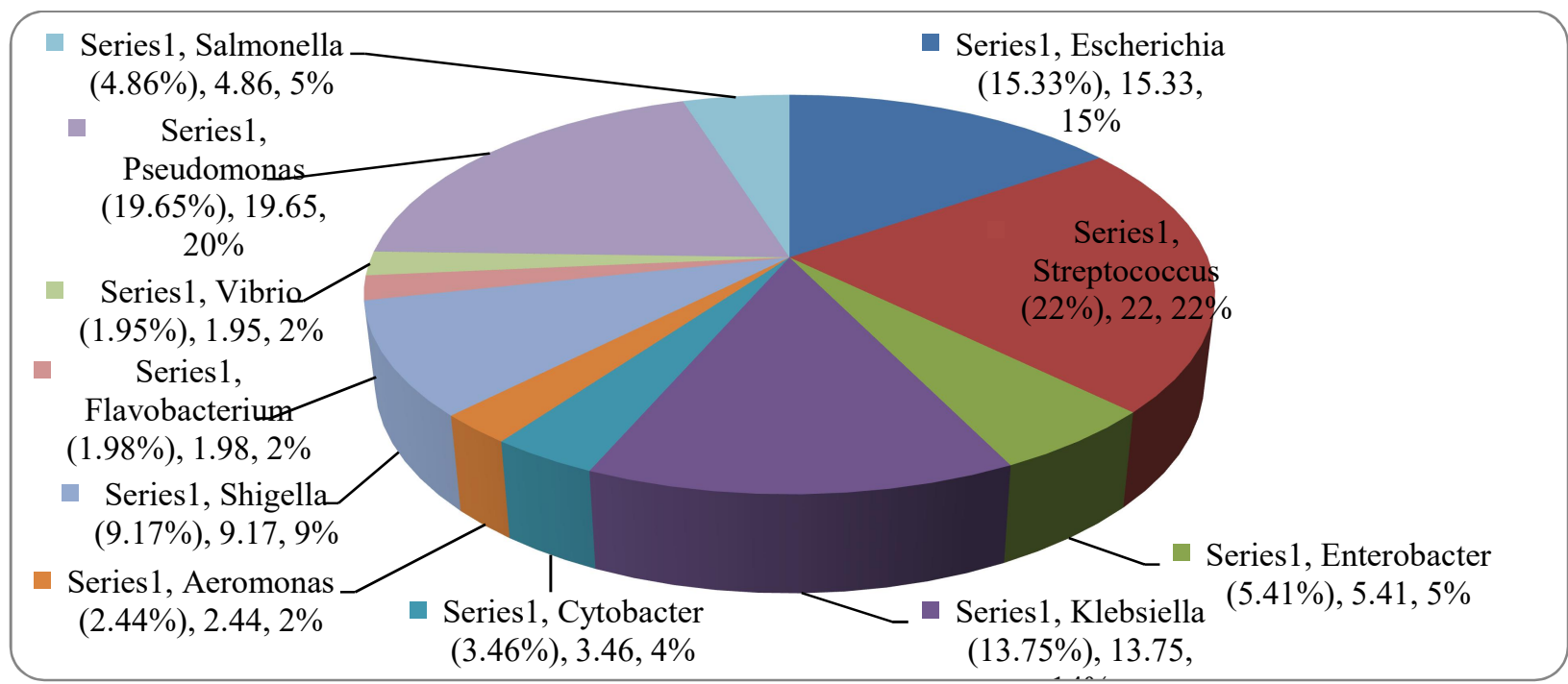

Fig, 3. Percentage composition of bacterial community in Kshipra River 
Kshipra Village is near to the origin point of the river and carries less organic pollution load. On the other hand, Mahidpur is located downstream the river, it is well known that the survival of pathogen is known to reduce after long distance (Abraham et al. 2007 and Shamnugan et al., 2016).

Composition and Variations of Bacterial Groups Escherichia is a group of, non-spore forming, gram negative facultative, anaerobic rod shaped bacteria from family Enterobacteriaceae. It is easily detected and is present abundantly in the environment, so it is majorly used as an index of fecal pollution of water. Therefore, its detection also indicates the presence of other pathogenic bacteria in a particular water body. In the present investigation, density of the genera ranged between $28-157 \times 10^{3} \mathrm{CFU} / 100 \mathrm{ml}$ where minimum is reported from Kshipra Village during the month of November and maximum is reported at Ramghat during the month of June. The genus contributes $15.33 \%$ of the total bacteria count, out of which E.coli is the most dominant species (Fig. 3).

Streptococcus is a genus of gram positive, coccus bacteria which are oxidase negative, catalase negative and are generally facultative anaerobes. Their density ranged between $55-239 \times 10^{3} \mathrm{CFU} / 100$ $\mathrm{ml}$ where highest is recorded during the month of June at Ramghat and lowest during the month of November at Kshipra Village. It has been observed as the most dominant genera contributed by $22.00 \%$ of total bacterial count. Among the genus, Enterococcus faecium, Enterococcus faecalis and Streptococcus agalactiae are observed continuously throughout the year at all study sites. Their continuous occurrence is attributed to the fact that these three species grow best at high temperature around $45^{\circ} \mathrm{C}$ and are capable of surviving alkaline conditions, heavy metal, bile salt, detergent, ethanol, azide and desiccation, Sankar and Paul (2015) observed Streptococcus density ranged between $8.2 \times 10^{4} \mathrm{CFU} / 100 \mathrm{ml}$ from Ganga river, Vsharani et al. (2010), reported Streptococcus count of $120 \mathrm{MPN} / 100 \mathrm{ml}$ from Noyyal river.

Enterobacter is a genus of anaerobic rod-shaped, gram negative, facultative, non-spore forming bacteria which can be pathogenic in nature. It is oxidase negative, indole negative and flourishes best in the presence of bile salts. The genus contributes about $5.41 \%$ of total bacterial count and its density lies between $7-75 \times 10^{3} \mathrm{CFU} / 100 \mathrm{ml}$ where its least density is reported at Kshipra Village during the month of December and maximum density is recorded from Ramghat study site during the month of April. The genera grows best at temperature between $35-37^{\circ} \mathrm{C}$ and carries remarkable capacity to tolerate adverse conditions as a result of which its maximum count is observed in the month of April. Its immense resistance for detergents, capacity to resist organic and inorganic pollutants are the reasons for its high count at Ramghat study site because this study site is regularly flooded with soaps and detergents due to massive and continuous mass baths. Omoigberale et al.,(2013) reported the presence of Enterobacter from river Ebutte Nigeria where its density is found to be high in summer season. Phanse et al., (2015) observed the presence of Enterobacter aerogenes from river Khan which is a tributary of river Kshipra. Klebsiella is a genus of gram negative, oxidase negative, motile, rod shaped bacteria which can be pathogenic in nature. Its density ranged between $21-174 \times 10^{3} \mathrm{CFU} / 100 \mathrm{ml}$ where highest is reported at Ramghat and lowest at Kshipra Village during the months of April and November respectively. The genus was contributed by $13.75 \%$ of total bacterial count and the most dominant species reported was Klebsiella granulomatis. Highest count of the genera has been observed in the month of April because the species of these particular genera grows best between $35-37^{\circ} \mathrm{C}$. They are recorded in comparatively high counts at Triveni, Ramghat and Mangalnath study sites because of the fact that they can recover from aquatic environments which continuously receives industrial waste water through Khan river (Caplenas et al., 1981). Anand et al. (2016), recorded Klebsiella from river Ganga, similarly Phanse et al., (2015) reported Klebsiella pneumoniae from river Khan India.

Citrobacter is Gram negative coliform bacteria which can accumulate uranium by building phosphate complex and can readily cause urinary tract infection, infant meningitis and sepsis. Its density ranges between $4-47 \times 10^{3} \mathrm{CFU} / 100 \mathrm{ml}$ where highest is reported at Ramghat during May and lowest at Kshipra Village during November and December. The genus is contributed by $3.48 \%$ 
Bhasin et al.

Table 1- Qualitative list of Bacteria recorded at different study sites of Kshipra river from Nov 2013 to Oct 2014

\begin{tabular}{|c|c|c|c|c|c|c|}
\hline $\begin{array}{l}\mathbf{S} \\
\mathbf{N}\end{array}$ & Organisms & $\begin{array}{l}\text { Kshipra } \\
\text { Village }\end{array}$ & Triveni & Ramghat & Mangalnath & Mahidpur \\
\hline A. & Escherichia & & & & & \\
\hline 1. & Escherichia coli & + & + & + & + & + \\
\hline 2. & Escherichia vulneris & + & + & + & + & + \\
\hline B. & Streptococcus & & & & & \\
\hline 1. & Enterococcus faecalis & + & + & + & + & + \\
\hline 2. & Enterococcus faecium & + & + & + & + & + \\
\hline 3. & Streptococcus agalactiae & + & + & + & + & + \\
\hline 4. & Streptococcus anginosus & + & + & + & + & + \\
\hline 5. & Streptococcus ictaluri & + & + & + & + & + \\
\hline C. & Enterobacter & & & & & \\
\hline 1. & Enterobacter aerogenes & + & + & + & + & + \\
\hline 2. & Enterobacter cloacae & + & + & + & + & + \\
\hline D. & Klebsiella & & & & & \\
\hline 1. & Klebsiella granulomatis & + & + & + & + & + \\
\hline 2. & Klebsiella oxytoca & + & + & + & + & + \\
\hline 3. & Klebsiella pneumonia & - & + & + & + & - \\
\hline 4. & Klebsiella terrigena & - & - & + & + & - \\
\hline 5. & Klebsiella planticola & + & + & + & + & + \\
\hline E. & Citrobacter & & & & & \\
\hline 1. & Citrobacter koseri & + & + & + & + & + \\
\hline 2. & Citrobacter freundii & + & + & + & + & + \\
\hline $\begin{array}{l}\mathbf{S} \\
\mathbf{N}\end{array}$ & Organisms & $\begin{array}{l}\text { Kshipra } \\
\text { Village }\end{array}$ & Triveni & Ramghat & Mangalnath & Mahidpur \\
\hline F. & Aeromonas & & & & & \\
\hline 1. & Aeromonas hydrophila & - & + & + & + & + \\
\hline G. & Shigella & & & & & \\
\hline 1. & Shigella boydii & + & + & + & + & + \\
\hline 2. & Shigella dysenteriae & + & + & + & + & + \\
\hline 3. & Shigella flexneri & + & + & + & + & + \\
\hline 4. & Shigella sonnei & - & - & + & + & + \\
\hline $\mathrm{H}$. & Flavo bacterium & & & & & \\
\hline 1. & $\begin{array}{l}\text { Flavo bacterium } \\
\text { columnare }\end{array}$ & + & + & + & + & + \\
\hline 2. & $\begin{array}{ll}\text { Flavo } & \text { bacterium } \\
\text { psychrophilum } & \\
\end{array}$ & + & + & + & + & + \\
\hline I. & Vibrio & & & & & \\
\hline 1. & Vibrio cholerae & - & + & + & + & - \\
\hline 2. & Vibrio fluvialis & - & + & + & + & + \\
\hline 3. & Vibrio parahaemolyticus & - & - & + & - & - \\
\hline
\end{tabular}

Environment Conservation Journal 
Bacterial diversity of river Kshipra

\begin{tabular}{|l|l|l|l|l|l|l|}
\hline & & & & & & \\
\hline J. & Pseudomonas & & & & & \\
\hline 1. & Pseudomonas aeruginosa & + & + & + & + & + \\
\hline 2. & $\begin{array}{l}\text { Pseudomonas } \\
\text { angulliseptica }\end{array}$ & - & + & + & + & + \\
\hline 3. & Pseudomonas putida & + & + & + & + & \\
\hline 4. & Pseudomonas fluorescens & + & + & + & + & + \\
\hline & & & & & & + \\
\hline $\begin{array}{l}\text { S } \\
\text { N }\end{array}$ & Organisms & Kshipra & Triveni & Ramghat & Mangalnath & Mahidpur \\
\hline K. & Salmonella & & & & & \\
\hline 1. & Salmonella anatum & + & + & + & + & + \\
\hline 2. & Salmonella paratyphi-A & + & + & + & + & - \\
\hline 3. & Salmonella paratyphi-B & + & + & + & + & + \\
\hline 4. & Salmonella typhi & + & + & + & + & + \\
\hline 5. & Salmonella typhimurium & + & + & + & + & - \\
\hline & & & & & & + \\
\hline L. & Fecal Coliform & + & + & + & + & + \\
\hline $\begin{array}{l}\text { M } \\
.\end{array}$ & Total Coliform & + & + & + & + & 29 \\
\hline & Total No. of species-35 & 26 & 32 & 35 & 34 & \\
\hline
\end{tabular}

where Citrobacter koseri is the dominant species, About 3\% of Citrobacter has been recorded from Thiba river Kenya (Muriuki et al., 2015). Aeromonas is genus of Gram negative, facultative, anaerobic, rod-shaped bacteria which is oxidase and indole positive and is associated with gastroenteritis. The genus is constituted by single species, Aeromonas hydrophila is reported to be absent at Kshipra Village and its density ranges between $3-37 \times 10^{3} \mathrm{CFU} / 100 \mathrm{ml}$ where, its highest density is reported at Ramghat in the month of April and lowest at Mahidpur in the months of September, October and December. The genus contributes $2.44 \%$ of the total bacterial count. Aeromonas is recorded from Venda river West Bengal (Obi et al., 2002).

Shigella is a genus of Gram negative, facultative, anaerobic, non-spore forming, rod-shaped bacteria causing dysentery. Entire genus counts for about $9.17 \%$ of the total bacteria in Kshipra river. Its density ranges between $7-93 \times 10^{3} \mathrm{CFU} / 100 \mathrm{ml}$ where highest is reported at Mangalnath in April and lowest at Kshipra Village during November and December and the most dominant species is Shigella dysenteriae. Higher counts of Shigella at Mangalnath are again attributed to the fact that Shigella can resist intense organic pollution, industrial pollution, domestic and city sewage.
Bibhas and Sharma (2013) recorded Shigella count $2.8 \times 10^{4} \mathrm{CFU} / 100 \mathrm{ml}$ from Barak river Assam.

Flavobacterium is a genus of non-motile Gram negative, rod-shaped bacteria whose density ranges between $2-43 \times 10^{3} \mathrm{CFU} / 100 \mathrm{ml}$ where highest is reported at Mangalnath in the month of March and lowest from Kshipra Village. However, the genera is not reported frequently at Kshipra Village and Mahidpur study site and the most dominant species out of the two is Flavobacterium columnare. Flavobacterium is a potent fish pathogen and has been reported to cause disease in fishes of Ganga river (Clifford 2011). However, in the present study a lower count of Flavobacterium is registered which indicates lesser risk to the fish community of the river.

Vibrio is a genus of Gram negative, rod-shaped facultative anaerobic bacteria positive for oxidase and its concentration in natural and sewage water is generally low, so it is cultured generally on enrichment media (APHA, 2005). The genus is contributed by $1.95 \%$ of the total bacterial count and the most dominant species is Vibrio cholerae which is pathogenic in nature and is the causative agent of Cholera. It was however, reported to be absent at Kshipra Village and Mahidpur whereas, its presence is registered during summer in Triveni, Mangalnath and Ramghat study sites respectively. Vibrio has less tendency to survive in natural and 


\section{Bhasin et al.}

sewage water and hence it is registered in comparatively lower counts in Kshipra river. However, it has been recorded from different rivers across the world, Mahapatra et al.,(2015) recorded Vibrio cholerae from Ganga river, Sharma and Chaturvedi (2007) recorded the presence of Vibrio sps. from Narmada river.

Pseudomonas is a class of heterogeneous and ecologically significant group of gram negative rod shaped, bacteria, generally found in soils, water, sewage, humans, animals, and plants. Its minimum density has been recorded at Mahidpur during the month of November and its maximum density has been reported at Ramghat in the month of June. The genus contributes about $19.65 \%$ of the total bacterial count and the most dominant species is Pseudomonas aeruginosa. Pseudomonas count in a river system is used to analyze hygienic status of a water body as the occurrence of some indicator bacteria like fecal coliform and species of Pseudomonas like P.aeruginosa indicate contact of river with sewage (Markosova and Jezek, 1994). Bhasin et al. (2015a) reported the presence of Pseudomonas from Kshipra river. Kumar et al. (2018) recorded the presence of Pseudomonas from different study sites of river Ganga and stated that Pseudomonas is a major reason behind community acquired and ventilator associated Pneumonia. The major reasons behind higher counts of Pseudomonas during summer season are attributed to the fact that during summer season increase in nutrient concentration and organic matter, reduction in water volume as well as addition of industrial and sewage effluents are significantly observed which support the growth of Pseudomonas there. Salmonella are ubiquitous, intestinal bacteria which are responsible for causing typhoid and paratyphoid fever in animals and humans. Salmonella infections may be food or water borne and are one of the major cause of concern in terms of public health. The minimum density of Salmonella has been recorded from Kshipra Village in the month of January and its maximum density has been recorded from Ramghat in the month of June. The genus contributes about $4.86 \%$ out of total bacterial count and the most dominant species out of the lot is Salmonella anatum. Addition of large amount of animal, human and fecal contamination is the main cause of higher count of $S$. anatum and river pollution. In the current sanario, the simple reason for higher count of Salmonella species during summer season may be attributed to reduced water level in summer which leads to an increased nutrient concentration, pollution load and reduction of water flow (Awah et al., 2013, Bhasin et al., 2015b). Reduced sanitation facilities in urban cities seems to be the main cause of higher bacterial pathogens in all prominent rivers which dissect major cities of the world. Million liters of untreated sewage is regularly discharged in river Kshipra which carries high bacterial load. The amount of water contaminated by sewage discharge and anthropogenic activities taking place on the banks of the river is directly proportional to occurrence of Salmonella. Population of Dewas and Ujjain districts are dependent on water of river Kshipra for irrigation, domestic and drinking purpose. The crops which are irrigated using this water are taken by the people residing in these cities and near by, which rises the outbreak of water borne diseases. Kumar et al., 2018 isolated Salmonella sps. from Yamuna river India.

The biological characteristics of water and wastewater are of fundamental importance to human health, in controlling diseases caused by pathogenic microbes of human origin and because of the role they play in decomposition of waste (Metcaff and Eddy, 2003). Fecal coliform generally points to bacteria having fecal origin like E.coli, Enterococcus faecalis and Enterococcus faecium. Similarly, total coliform points to bacteria which are permanent residing in human intestine and may be found anywhere in soil, water, air or in human and animal excreta. They include genera like Escherichia, Klebsiella, Citrobacter, Enterobacter and Streptococcus. Fecal coliform (FC) are associated with bacteria residing specifically in the gut region and feces of humans and animals. Due to their large number and long survival time in water they can be easily detected and are generally referred as an evidence for the occurrence of interstitial pathogenic bacteria in water. The values of fecal coliform lied between $72-106 \times 10^{3} \mathrm{CFU} / 100$ $\mathrm{ml}$ at Kshipra Village, $158-290 \times 10^{3} \mathrm{CFU} / 100 \mathrm{ml}$ at Triveni, 202-322 $\times 10^{3} \mathrm{CFU} / 100 \mathrm{ml}$ at Ramghat, 189$298 \times 10^{3} \mathrm{CFU} / 100 \mathrm{ml}$ at Mangalnath and 89$112 \times 10^{3} \mathrm{CFU} / 100 \mathrm{ml}$ at Mahidpur. At the same time, TC count was found to oscillate between 138$198 \times 10^{3} \mathrm{CFU} / 100 \mathrm{ml}$ at Kshipra Village, 306$600 \times 10^{3} \mathrm{CFU} / 100 \mathrm{ml}$ at Triveni, 390- 
$768 \times 10^{3} \mathrm{CFU} / 100 \mathrm{ml}$ at Ramghat 358$694 \times 10^{3} \mathrm{CFU} / 100 \mathrm{ml}$ at Mangalnath and 158-212 $\mathrm{x} 10^{3} \mathrm{CFU} / 100 \mathrm{ml}$ at Mahidpur. Highest FC and TC count has been observed at Ramghat study site during the month of June and lowest has been observed at Kshipra Village during the month of November. Out of the total bacterial count, Fecal coliform accounts for $25.18 \%$ and TC accounts for $59.99 \%$. During summer, suitable environmental conditions for bacterial growth, indiscriminate defecation by both humans and other animals that graze along the riverside, reduced water level and high nutrient concentration are available which are the main reasons for higher count of bacteria during this season. Shrivastava et al., (2011) found higher FC count during the monsoon season from Gomti river, Shawky and Rabeh (2007) observed FC counts ranged between $21-7500 \times 10^{3} \mathrm{CFU} / 100 \mathrm{ml}$ $\mathrm{CFU} / 100 \mathrm{ml}$ and TC count ranged between 240 $1,60,000 \times 10^{3} \mathrm{CFU} / 100 \mathrm{ml} \mathrm{CFU} / 100 \mathrm{ml}$ from Nile river Egypt, where highest count has been recorded during the summer season. Aishwarya et al., 2018 reported high FC count from river Jatganga India during summer season. However, in the current study high FC and TC counts have been observed in river Kshipra which confirm the contamination of the river water by fecal matter, industrial effluents, anthropogenic activities and discharge of domestic and city sewage in the river and indicates the presence of pathogenic organisms.

Fecal Coliform and Fecal Streptococci Ratio (FC/FS Ratio)

FC/FS ratio means ratio of fecal coliform to fecal Streptococci where, out the reported species in the present study, fecal coliform includes Escherichia coli, Enterococcus faecalis and Enterococcus faecium and fecal Streptococci includes Enterococcus faecalis and Enterococcus faecium. FC/FS ratio ranged between 1.1-2.2 at Kshipra Village, 1.2-1.4 at Triveni, 1.1-1.5 at Ramghat, 1.21.4 at Mangalnath and 1.0-1.3 at Mahidpur. FC/FS ratio is very important and it is indicated that (FC/FS) ratio of 4 or more indicates water contamination of human origin and FC/FS less than 0.7 indicates contamination from animal origin. $\mathrm{FC} / \mathrm{FS}$ ratio is an important tool for analyzing the source of feces if ratio is $(>4)$ then contamination is of human origin and if it is less than $(<0.7)$ hence, the contamination is of animal origin and if values are between 0.7 and 4 then contamination is from both animal and human feces. Shawky and Rabeh (2007) reported FC/FS ratio ranged between 0.1911.00 which depicted contamination of human origin. Omoigberde et al., (2013) observed higher fecal coliform than fecal Streptococci and low $\mathrm{FC} / \mathrm{FS}$ ratio suggesting the river's contamination by animal excreta. However, in case of Kshipra river FC/FS ratio between 1.1-1.5 indicates that the river is contaminated by domestic and city sewage as well as by both animal and human excreta.

Bacterial diversity and its relation with physic chemical parameters

It is well- known that a clear and evident correlation exists between physicochemical parameters and growth and development of various microorganisms. Temperature of the water is also considered as determining factor for seasonal distribution of fauna and flora (Bhasin et al., 2015c). Bacterial diversity is naturally occurring which may occur with regularity depending on weather and water conditions of the river and is positively correlated with temperature (Liu et al., 2019). Bacterial flora is widely influenced by organic pollutants more than any other factor. According to the spatial distribution of bacterial diversity and density, Mangalnath, Ramghat and Triveni are known to be leading sites. This may be due to the fact that these sites also witness higher organic pollution load, $\mathrm{pH}$, ox disable organic matter, carbonate, bi-carbonate, BOD, COD and low DO.

It is a well established fact that variations in physicochemical parameters affect bacterial count in rivers. During summer season, high temperature, turbidity, $\mathrm{pH}, \mathrm{BOD}, \mathrm{COD}$ and low $\mathrm{DO}$ are recorded which favor and enhance the growth of bacteria but as these factors reduce from summer to monsoon and winter a similar reduction in bacterial diversity and density is observed. Similar finding have been observed by Alegbeleye et al., (2016) from Diep and Plankenburg river system Western Capetown, South Africa who reported bacterial density ranged between $3.1-6.9 \times 10^{3} \mathrm{CFU} / 100 \mathrm{ml}$ where highest density has been recorded during summer season. Shannugan et al.,(2016) recorded bacterial density ranged between 5.9-6.7 9x10 $0^{3} \mathrm{CFU} / 100 \mathrm{ml}$ from Cooum river where again high density has been registered during summer season. Anand et al., (2016) observed higher count in dry season in Yamuna river New Delhi. The trends are in 
agreement with Neuman et al.,(1972) who stated that in tropical countries the seasonal cycle of microorganisms can be correlated to lower count in winter and higher in summer.

\section{Bacteria and Human Health}

One of the most common disease causing pathogens which are potentially transmitted through water are bacteria. These organisms generally enter via food and water, affect the gastero intestinal tract and are excreted in feces of infected human and other animals (Rodriguez and Navelo, 2017). Route of transmission of these bacteria include inhalation, contact with person having infections in respiratory tract, bathing in water and skin lesions. The study registers the presence of certain pathogenic bacteria in water and analyses their effect on health. Pathogenic bacteria related to health include Escherichia (urinary track infections and diarrhoea), Streptococcus (Urinary tract infections, sepsis and meningitis) Aeromonas (respiratory tract infections), Klebsiella (infections in immune compromised patients), Pseudomonas aeruginosa (skin and pulmonary infections and gasterointestinal infections), Salmonella sps. (Entric fever, typhoid and Salmonellosis), Shigella sps. (dysentery and watery diarrhoea), and Vibrio sps.(Cholera and gasterointestinal disturbances).

Diarrhea may result due to infection of E.coli whereas, urinary track infection are results of pathogenic effect of E.coli, Streptococcus agalactiae or Enterococcus faecalis. In the present study, $12.2 \%$ cases of diarrhea and $8.3 \%$ cases of urinary tract infection are recorded out of the total registered cases at office of the Chief Medical Officer of Ujjain and Dewas districts. The present study reports $13 \%$ cases of enteric and $8 \%$ cases of typhoid fever and $3.4 \%$ cases of salmonellosis of the total registered cases at the office of CMO Ujjain and Dewas districts. A high percent of cases of enteric, typhoid fever and salmonellosis are reported due to improper waste disposal, sewage entry in water. During the investigation period $10.2 \%$ cases of respiratory infections, $11.6 \%$ cases of skin infections and $15.8 \%$ cases of gasterointestinal infections from Ujjain and Dewas districts have been reported which are known to be caused by Pseudomonas aeruginosa respectively. The present study reports $3.1 \%$ cases of Shigellosis which is caused by Shigella species. In the current study $2.8 \%$ cases of cholera characterized by loose, watery and mucous-flecked. "Rice-Water" stools and caused by Vibro cholerae have been reported from peoples who are dependent on river water. Several workers in India and across the globe have worked on water borne infections arising from bacteria (Tyagi et al., 2007, Treadway 2016). In the present study, it is clearly evident that bacterial population is directly related with causing different types of disorders and diseases in human population residing near by river water so adequate precautions should be taken before consumption of water.

\section{Conclusion}

The present investigation concludes that Kshipra river is demarked by presence of different bacterial species including fecal coliforms like E.Coli and Streptococcus which not only indicate contamination of river by fecal matter but also indicates the presence of pathogenic bacteria like Salmonella sps., Shigella sps., Pseudomonas sps. and Vibrio sps. The presence of bacterial community is found to be maximum during summer season due to reduction in water level and increase in temperature which increases nutrient concentration and lowers the dissolved oxygen level in river water.

As far as the site wise distribution is consent Ramghat study site is found to show maximum bacterial diversity and density followed by Mangalnath and Triveni sites respectively as Ramghat study site witness maximum anthropogenic activities and is the major mass bathing center of the city. The study also reports presence of some deadly water borne infections like Typhoid, cholerae, gastrointestinal diseases and skin infections etc in people residing nearby river who are dependent on river water for fulfillment of their daily need. Kshipra river is a low flowing river with comparatively less self- purification properties, thus it has less capacity to purify pollutants. As, a result of this the river remains highly polluted throughout and the river water is unfit for consumption without proper treatment. So, proper action should be taken by local and government authorities to minimize pollution load, prohibit anthropogenic activities and create social awareness among people for preservation of this holy river. 


\section{Bacterial diversity of river Kshipra}

\section{References}

Abraham, W.R., Macedo, A.J., Gomes, L.H. and Tavares, FCA. 2007. Occurrence and resistance of pathogenic bacteria along the Tiet's river downstream of Sao Paulo in Brazil. Clan 35(4): 339-347.

Alegbeleye, O.O., Opeolu, B.O., Jackson, V.A. 2016. Investigations into the bacterial population at various sites along the Dielp and Planken lewig river system, Western Cape S.A. (Density $3.1-10^{5}-6.9 \times 10^{8}$ CFU/ml Bacillus Pseudomonas, Klebsiella, Escherichia, Enterobacter, Serrentia, Aeromonas, Staphylococcus and Citrobacter, high in summer). Water Science and Technology, 73(11): 54-64.

Anand, C., Akolkar, P., Chakrabarti R. 2016. Bacteriological water quality status of river Yamuna, Delhi. Environ. Biol. 27: 97-107.

Aishwarya, Nidhi., Malviya, M., Tamhe Ashish., Sati, Priyanka., Dhakar Kusum and Pandey Anita. 2018 Bacteriological assessment of river Jatganga, located in Indian Himalaya, with special reference to physicochemical and seasonal variations under anthropogenic pressure- A case Study.

APHA 2005. Standard Methods for the Examination of Water and Wastewater, $21^{\text {st }}$ edn (American Public Health Association WWA, Washington, D.C.).

Awah, Margaret TITA., Alice, MAGHA. and Kabeyene, Beyala. 2013. Microbial pollution of Mezan river system and its health impact in Bamenda (North-west Cameroon). African Journal of Microbiological research, 7(42): 49404948.

Bergey's Manual of Systematic Bacteriology 1985. Book Review, Int. J. of Syst. Bact; July !985, P 408.

Bhasin, Shivi, Shukla, Arvind N., Shrivastava, Sharad. 2015 A. Observation on Pseudomonas aeruginosa in Kshipra River with Relation to Anthropogenic Activities. Int. Journal Current Microbiol App. 4 (4): 672-684.

Bhasin, Shivi, Shukla, Arvind N., Shrivastava, Sharad. 2015 B. European Journal of Pharmaceutical and Medical Research, (4) : 461-481.

Bhasin, Shivi, Shukla, Arvind N., Shrivastava, Sharad 2015 C. Observation on Physicochemical and Microbiological parameters of Kshipra river with special relation to water quality. IJ $\boldsymbol{A} \boldsymbol{L} \boldsymbol{S}$ 8(2): 125-138.

Bhasin Shivi 2016 D. Water Quality Monitoring of River Kshipra with Special Reference to Microorganism. Ph.D thesis, Vikram University, Ujjain M.P. India.

Bibhas, Rajkumar. and Sharma, G.D. 2013. Seasonal bacteriological analysis of river, Barok, Assam. App. Water Science, 3(3): 625-630.
Bhutiani, Rakesh and Khanna, D.R. 2002. Bioremediation of pulp and paper mills effluent using microbial consortia. $J r$. Nature env. \& Poll. Tech. 1(4): 361-363.

Caplenas, N.R., Kanarek M.S. and Dufour A.P. 1981. Source and extent of Klebsiella pneumonia in the paper industry. Appl. Environ. Microbiol., 20: 1-3.

Clifford, E. Starlip 2011. Bacterial coldwater disease of fishes caused by Flavobacterium psychrophilum. South African Journal of Science, 2(2): 97-108.

Khanna, D.R., Pathak, S.K., Bhutiani, R. and Chandra, Kumar S. 2006. Study of Water quality of River Suswa near Raiwala, Uttaranchal. Env. Cons. Journal Vol. 7 (3): 7984.

Khanna, D.R., Bhutiani, R. , Pathak, S.K., Tyagi, Prashant and Tyagi, Bharti 2008. Effect of tourism on the physicochemical parameters of stream Nalhota at guchu Pani, District Dehradun (India): Env. Cons. Jr. Vol-9No. (3):109-115

Khanna, D.R., Bhutiani, R., and Kulkarni, Dipali Bhaskar 2011 .A study on pollution status and its impact on water quality of River Ganga at Haridwar. Environment Conservation Journal. Vol 12(1\&2):9-15

Kochling, Thorsten, Saz Luis Jones., Galdino, Luiz., Florencio, Loudinha. and Kato, Mario. 2017. Int. Microbiology, 20 (1): $11-24$

Kumar, Anurag, Benjamam C. J., Kumari, Arti and Kumar Hemant. 2018. Isolation and Identification of Bacterial Strains from Yammuna river at Allahabad district in U. P. India. Int J. Curr. Microbiol. App. Science, 7 (12): 30133032 .

Liu, Jie,. Tu, Ting., Guanghai, Gao., Berftian, Mark., Wang, Yingying,. 2019. Biogeography and Diversity of fresh Water bacteria on a river catchment area. Microbial Ecology, 72(4): 741-986.

Metcalf and Eddy 2003. Waste Water Engineering Treatment and Reuse. Fourth edition, New York, USA: MC Graw Hill.

Mahapatra, S.S., Mantri C.K., Bhotra, T., Singh, D.V. 2015. Characteristics of Vibrio cholerae isolated from water of river Ganga Varanasi. Indian Journal of Medical Microbiol. 33(4): 507-51.

Markosova, R. and Jezek, J. 1994. Indicator bacteria and limno logical parameters in fish ponds. Water Res., 12:24772485 .

Mitsch, W.J., Grosselink, J.G. 2000. Wetlands, 920 P. Wiley, New York, USA 
Muriuki, Wambui Emily., Ethy, Kang Stanley., Mevangi, Jonathan. and Suleman,Mboruk., 2015. Morphological Characterization of Enteric pathogens in Thiba river of Kirinyaga county, Kenya. Int. Journal of life science research., 3(3):10-19.

Newmann, D.A., Beneson, M.W., Hubster, E., Iwan, N.T. and Tien-Van L 1972. Vibrio parahaemolyticus in the Republic of Vietnam. Atm. J. Trop. Med. Hygeine., 21(4): 464-466.

Obi, CL., Potgieter, N., Bessong, P.O. and Matsaung, G. 2002. Assessment of the microbial quality of river water sources in rural Venda communities in South Africa.

Water SA 28(3): 287-292.

Omoigberde, May N.O., Jonathan, O., Isibor., Joshua, I. Izegagbe. and Iyamu L. Mercy. 2013. Seasonal variations in the bacteriological quality of Ebutte river in Ehor Community, Edo state, Nigeria, 2013. American Journal of Research Communication, 1(7): 59-69.

Phanse, Nandini., Mishra, Vartika. and Agrawal, Shivangi. 2015. Bacteriological assessment of water samples of Indore city. A study of prevalence of drug resistant bacteria. IJRSB: 3(7):72-79.

Rodriguez, Lilla and Navelo Morales 2017. Bacterial Pollution in river water and gastrointestinal diseases :Int. $J$. Environ Res Public Health: 14 (5): 479-483.

Sharma, A. and Chaturvedi, A.N. 2007. Population dynamics of Vibrio species in river Narmada at Jabalpur. J. Environ. Biol., 28 (4): 747-51.

Shawky, Z. Sabae and Saleh, A. Rabeh. 2007. Evaluation of microbial quality of the river Nile water at Damietta Branch, Egypt. EJAR 33(1):301-311.
Shrivastava., Anukool. and Shrivastava, Shivani. 2011. Assessment of physico- chemical properties and sewage pollution indicator bacteria in surface water of river Gomti in U.P. Int. Journ. of Env. Science., 2(1): 325 - 333.

Shamnugan, Jayshree., Pennswamy, Gopal., Mayakkannan. and Shadri, Sundaram 2016. Population dynamics and seasonal variations of bacterial system utilizing single carbon from river Coousm and river Adyar, Chennai. T.N. IJCMAS 5(3):466-477.

Treadway, Tayler. 2016. Toxins in Lagoos could trigger disease. Environment 30:11-12.

Tyagi, V.K., Chopra, A.K., Kazmi A.A., Kumar A. 2007. Alternative microbial indicators of fecal pollution. Current perspective, Iran J. Environ. Health. Sci. Eng., 3(3): 205-216

Vsharani, K., Umarani, K., Ayyasami, P.M., Shanthi, K., Lakshmanakerumasamy, P. 2010. Physico-chemical andbacteriological characteristics of Noyal river and ground water quality of Perur, India. Int. Journal. of Env. Science, 2: 12-15.

Whiteman, W.B., Goodfellow, M., Kampher, P., Busse, H.J., Trujillo, M.E., Ludwick., Suzuki, K.I. and Parte, A. 2012. Bergy Manual of systemic $\quad$ Bacteriology $4 \quad\left(2^{\text {nd }}\right.$ edition). New York Spinger p.1750.

Zhan, Hao Fang., Ying, Zhang., Chengu, Liu., Guanghe, Zheng., Wei, Leyuguen and San, Dan. 2020. Different Response of Bacterial Community to the changes of nutrients and pollutants in sediments from urban river network. Frontiers of Env. Science, Article no. 4. 